ШАЛЫГИНА Наталья Валентиновна - кандидат исторических наук, старший научный сотрудник Института этнологии и антропологии им. Н.Н. Миклухо-Маклая, РАН (119334, Россия, г. Москва, Ленинский пр-кт, 32A; etgender@таil.ru)

СНЕЖКОВА Ирина Анатольевна - кандидат исторических наук, старший научный сотрудник Института этнологии и антропологии им. Н.Н. Миклухо-Маклая, РАН (119334, Россия, г. Москва, Ленинский np-кm, 32A; snezhkova@ mail.ru)

\title{
СТАНОВЛЕНИЕ И ПЕРСПЕКТИВЫ РАЗВИТИЯ ЭТНОГЕНДЕРНЫХ ИССЛЕДОВАНИЙ В РОССИИ
}

Аннотация. Статья посвящена рассмотрению основных этапов становления такого достаточно нового направления в отечественных гуманитарных науках, как этногендерные исследования. Особое внимание авторы уделяют трудностям развития этногендерных исследований в перестроечный и постперестроечный периоды современной России, разработке методик и определению проблемных блоков, поиску взаимопонимания с феминистскими течениями и взаимодействию с западными научными школами. Ключевые слова: гендерные исследования, этнология, феминизм, междисциплинарность, полоролевое поведение, социальное конструирование

\footnotetext{
$\mathrm{C}$
} тановление этногендерных исследований в российской науке было инициировано сотрудниками Института этнологии и антропологии РАН им. Миклухо-Маклая (ИЭА РАН) в начале 1990-х гг. Методологически деятельность нового сектора этногендерных исследований (СЭГИ) изначально задумывалась как междисциплинарная, которая соединяла бы в себе не только исследовательские усилия других подразделений ИЭА РАН, но и результаты изысканий ученых смежных институтов Российской академии наук - социологов, историков, психологов, демографов, искусствоведов, лингвистов и т.д., прямо или косвенно затрагивавших проблематику полоролевого поведения.

Концепция СЭГИ на первом этапе своего становления состояла в том, чтобы показать (и доказать) реальное многообразие и культурную самодостаточность различных форм гендерных отношений в мире, объективную обусловленность их возникновения и развития под воздействием целого ряда региональных факторов (климатических, ландшафтных, экономических, генетических и др.). Создание такой своеобразной «гендерной карты народов мира» позволило бы не только объяснить эволюционные подвижки в гендерных отношениях представителей различных культур, но и вполне креативно соотносить подобного рода изменения с социальными теориями различных направлений.

Основное внимание в работе вновь созданного СЭГИ в это время уделяется результатам полевых исследований сотрудников ИЭА РАН, которые на протяжении десятилетий проводились в различных регионах СССР, а с 1991 г. - на территории Российской Федерации и некоторых бывших советских республик. Экспедиционная фактография, собранная несколькими поколениями сотрудников ИЭА РАН и хранящаяся в архивах института в виде полевых дневников, а также аудио-, кино- и видеоматериалы позволили из первых рук получать информацию об этнокультурных различиях в традициях мужчин и женщин нашего многонационального государства. Учитывались не только артефакты материальной культуры (одежда, пища, украшения, домашняя утварь, убранство мужской и женской половины крестьянского дома, орудия труда и т.д.), но и эволюция духовной жизни населения национальных республик (верования, свадебные и родильные обряды, запреты, обычаи поведения и т.д.). 
Шаг вперед в развитии СЭГИ, как предполагалось, должен был обеспечить междисциплинарный проект, соединяющий методологические концепты лаборатории пластической реконструкции М.М. Герасимова и данные советских этнографических исследований на северо-востоке СССР (Чукотка). Для реализации этого проекта в 1991 г. началась подготовка к международной этнографической выставке в г. Сан-Хуане (Пуэрто-Рико), где сотрудники СЭГИ на основе нескольких антропологических реконструкций выдвинули гипотезу о различных адаптационных возможностях мужчин и женщин в процессе освоения Северо-Восточного региона. Однако участие СССР в международной этнографической выставке в г. Сан-Хуан так и не состоялось в результате происшедшей в декабре 1991 г. геополитической катастрофы и распада СССР как государственного субъекта.

Тем не менее междисциплинарность в качестве основного методологического принципа этногендерных исследований получила свое дальнейшее развитие в работе СЭГИ, чему способствовало как минимум два объективных обстоятельства. Во-первых, сама первичная группа молодых ученых, решивших заняться изучением гендерных проблем, тогда состояла исключительно из специалистов в области американистики. А во-вторых, в период выделения СЭГИ в самостоятельное структурное подразделение многие ученые-зарубежники института разрабатывали тему семьи и семейных отношений как приоритетную в общем научно-исследовательском плане ИЭА РАН. Результатом совместной работы историков и антропологов в области фамилистики стало издание коллективной монографии «Семья у народов Америки» [Семья... 1991]. Общая исследовательская концепция коллективной монографии включала в себя обязательное раскрытие этнорасовых проблем «мужского» и «женского» в Северной, Центральной и Южной Америке, особенности домашней жизни с точки зрения полоролевого поведения, городские и сельские нюансы отношений полов, частично - государственную политику (без специальной артикуляции правовых вопросов, но с учетом временных изменений в регуляции семейных отношений в целом со стороны государственных властей той или иной страны).

Не менее перспективным оказалось и взаимодействие с социологией. Попытки взаимопроникновения социологических и антропологических методик в рамках отечественных гендерных исследований предпринимались и до возникновения этногендерных исследований в структуре ИЭА РАН, непосредственно накануне и в год развала СССР. Правда, инициированы эти попытки были не отечественными учеными, и даже вовсе не учеными. В 1990 г. жена одного из высокопоставленных сотрудников посольства Мексики в Москве Анна-Мария Г., активная участница женского движения в Мексике, обратилась с предложением к социологам, этнологам, психологам и демографам г. Москвы провести комплексное анкетирование женщин в крупных городах нашей страны, включая Среднюю Азию и Северный Кавказ, с целью ответа на вопрос, что же из себя представляет «феномен советской женщины».

Несмотря на недостаточно академический уровень российско-мексиканского исследования 1990-1991 гг, оно, безусловно, оказалось историческим, т.к. проводилось в период распада советской политической системы в нашей стране, а значит зафиксировало то состояние менталитета советских женщин, которое уже было «уходящей натурой», со всеми вытекающими отсюда выводами. Кроме того, анкетирование женщин оказалось и самым масштабным на тот период, т.к. охватило более двух десятков советских городов, что также позволяет отнести полученный опыт междисциплинарного исследования к разряду уникальных. 
Летом 1993 г. СЭГИ (совместно с коммерческой фирмой «Ларина-сервис») впервые проводит в Москве крупнейшую в Новейшей истории России международную конференцию «Женщина и свобода», которая объединила всех специалистов, ориентированных на феминистскую тематику [Женщина и свобода... 1994]. Однако размах тематики конференции, можно сказать, захлестнул к тому времени еще не до конца созревшую самостоятельность этногендерного проекта и фактически включил его в феминистский дискурс. А учитывая тот факт, что феминистские теории евро-атлантического образца к 1990-м гг. представляли собой уже вполне убедительный идеологический продукт, развитие этногендерного проекта на ближайшие годы в известной степени оказалось предопределенным.

Нельзя не учитывать и то обстоятельство, что большинство научных проектов в 1990-х гг., по сути, были лишены государственного финансирования на фоне общего драматизма смены социально-политической формы правления и экономической разрухи в нашей стране. Каких-либо внятных представлений о будущем гуманитарной науки в те годы попросту не существовало. Следуя феминистским теориям, первоначальное направление исследований СЭГИ, ориентированное на сравнительное изучение особенностей мужского и женского поведения, а также на концепцию биологического детерминизма (неоспоримость бинарной оппозиции «мужского» и «женского» в социокультурных процессах), постепенно замещается концепциями социального конструирования гендера (П. Бергер, Т. Лукман, К. Уэст, Д. Зиммерман), сопряженными с такими классическими направлениями социальной теории, как структурный функционализм Э. Дюркгейма, полоролевая теория Т. Парсонса, драматургический интеракционизм И. Гоффмана и т.д.

При сложившихся обстоятельствах этногендерный проект, как и многие другие гуманитарные проекты того времени, оказался в положении аффилированной структуры, когда в обмен на продвижение в российское общественное сознание феминистских идей (причем не только либеральных, но и радикальных) исследователи получали некоторое финансирование от зарубежных фондов (прежде всего, фонда Маккартуров и фонда Г. Форда), возможность участвовать в конференциях, семинарах и т.п. Очевидным плюсом такого положения вещей, правда, стала возможность для российских специалистов не только обмениваться идеями и исследовательскими методиками между собой, но и получать представление о передовых западных наработках в области трансформации гендерных отношений. К тому же отказ западной социологии на тот момент от изучения исключительно социальных ролей индивидов (позитивистский подход) в пользу изучения самих исполнителей этих социальных ролей и вариаций их социального выбора (теория символического интеракционизма Дж. Мида, драматургического интеракционизма И. Гоффмана и др.) не просто был понятен антропологам, но и активно ими использовался как классический метод социально-антропологических исследований.

Проведенные в 1990-х гг. на основе этого метода этногендерные исследования позволили сделать несколько значимых выводов об особенностях менталитета российской молодежи переходного периода. Так, было установлено, что девушки-старшеклассницы занимали в тот период более активную по сравнению со своими сверстниками социальную позицию (например, в ситуациях спонтанно возникающих этнических конфликтов проявляли откровенную готовность встать на защиту тех, кто оказывался в роли притесняемых) [Котовская, Шалыгина 1995].

Молодые россиянки 1990-х гг. оказались также более активными, чем их сверстники-мужчины, и в вопросах планирования личной жизни. Масштабные 
социально-экономические трансформации, проводившиеся в новой России, фактически спровоцировали резкую смену брачных установок среди девушек и привели к формированию модели их поведения, ориентированной почти исключительно на статусные и финансовые характеристики будущего партнера. Сама система поиска брачного партнера оказалась лишенной хоть сколько-нибудь вразумительной эмоциональной мотивации, а собственные данные будущие жены и матери в нашей стране позиционировали в те годы почти исключительно как товарную категорию [Котовская, Шалыгина 2013].

Главная трудность, с которой столкнулся исследовательский коллектив СЭГИ при анализе молодежных реакций на активно внедрявшиеся в их сознание западные ценности, заключалась в интерпретации ключевых мировоззренческих понятий темы. С позиций постпозитивистской социологии, утвердившейся в гуманитарном знании несколькими годами ранее, общество - это вид дискурса, один из вариантов текста, который в разные времена может читаться разными способами. Постсоветское общество середины 1990-х гг. «читалось» двояко: и как «смутное время» потери ориентиров национального государственного развития, и как время новых возможностей. Подобного рода дихотомия «плюсов» и «минусов» в оценке происходивших тогда событий (сохраняющаяся, кстати, и сегодня) предопределила мировоззренческую платформу всего этого исследовательского направления. Результаты анализа показали, что мировосприятие российской молодежи в быстро меняющихся социально-экономических и политических условиях откровенно диверсифицировано, разобщено, раздроблено. И изучать новую реальность надо было именно в междисциплинарном ключе антропологической науки в целом (медицинская антропология, юридическая антропология, этология, коммуникативная антропология и т.д.). Однако все ответвления антропологии в то время только становились на ноги в отечественной науке, в силу чего полноценное раскрытие темы стало делом будущего.

Помимо социально-антропологического анализа внутрироссийской ситуации, этногендерные исследования с самого начала были направлены и на изучение проблем, связанных с интеграцией нового российского социума в общемировое пространство. Реализация нескольких исследовательских проектов, посвященных миграционным процессам, позволила сделать вывод о различии адаптационных возможностей мужчин и женщин. Концепция более органичной и менее травматичной схемы вхождения женщин в инокультурную среду (по сравнению с мужчинами) получила название «гендерного дифференциала социокультурной адаптации» [Шалыгина 2007: 58-60]. Концепция была успешно апробирована при изучении перспектив женщин - трудовых мигрантов в российских городах (совместный российско-итальянский проект 2009-2011 гг.), трудностей повседневной жизни жен русскоязычных программистов в США (пролонгированный проект 2003-2018 гг.), при сравнении гендерных моделей успешности представителей этнических диаспор в Москве и др. Кроме того, по результатам научных исследований и в рамках деятельности общественных организаций проводились тренинги по обучению социальных работников и представителей администраций регионов особенностям работы с мигрантами.

С середины нулевых годов этногендерные исследования ИЭА РАН активно сопрягаются с деятельностью Российской ассоциации исследователей женской истории (РАИЖИ, рук. Н.Л. Пушкарева). Ежегодные конференции РАИЖИ проходят в разных городах России и охватывают весьма широкое информационное пространство. Тематический диапазон статей включает в себя такие направления, как изучение медико-биологических проблем, связанных с раз- 
витием женского организма в постчернобыльской реальности; этологические аспекты формирования гендерных ролей в современных этносах; категоризация образов идеальной супруги (супруга) в средневековой Руси; проблемы политической корректности и гендерного этикета в США; трансформация стереотипов мужественности в традиционной и современной культурной среде и многие другие.

Тематическая широта этногендерных исследований, безусловно, обеспечивает им понятийную глубину и поддержку со стороны методологической базы самых различных дисциплин. Но, в свою очередь, именно использование междисциплинарных методик предоставляет этногендерным исследованиям не только перспективы дальнейшего развития, но и возможность применения сделанных выводов на практике. А это обстоятельство, как представляется авторам, является гарантией востребованности научного направления в современном обществе.

\section{Список литературы}

Женщина и свобода: пути выбора в мире традиций и перемен: материалы международной конференции. Москва, 1-4 июля 1993 г. 1994. М.: Изд-во ИЭА. 445 с.

Котовская М.Г., Шалыгина Н.В. 1995. Этнические факторы насилия в среде московских школьников. - Среда и культура в условиях общественных трансформаций. М.: Изд-во фонда Карнеги. С. 224-237.

Котовская М.Г., Шалыгина Н.В. 2013. Слом гендерных стереотипов в массовом сознании россиян. - Российская гендерная история с «юга» на «запад»: прошлое определяет настоящее: материалы VI Международной научной конференции РАИЖИ и ИЭА РАН. 3-6 октября 2013 г. Нальчик. С. 160-165.

Семья у народов Америки (А. Богина, А.Д. Дридзо, М.Г. Котовская и др.; отв. ред. Ш.А. Богина). 1991. М.: Наука. 314 с.

Шалыгина Н.В. 2007. Кризис семьи в эмиграции (США, пуэрториканская модель). М.: Изд-во ИЭА РАН. 251 с.

SHALYGINA Natalya Valentinovna, Cand.Sci. (Hist.), Senior Researcher at the Institute of Anthropology and Ethnography, RAS(32A Leninsky Ave, Moscow, Russia, 119334; etgender@mail.ru)

SNEZHKOVA Irina Anatol'evna, Cand.Sci. (Hist.), Senior Researcher at the Institute of Anthropology and Ethnography, RAS (32A Leninsky Ave, Moscow, Russia, 119334; snezhkova@ mail.ru)

\section{FORMATION AND DEVELOPMENT PROSPECTS OF ETHNO-GENDER STUDIES IN RUSSIA}

\footnotetext{
Abstract. The article is devoted to the consideration of the main stages of the formation of a new direction in the domestic humanitarian sciences - ethno-gender studies. The authors pay particular attention to the difficulties of developing ethnogender studies in the perestroika and post-perestroika periods of modern Russia, of developing methods and identifying problem blocks, searching for mutual understanding with feminist movements and interacting with western scientific schools. Keywords: gender studies, ethnology, feminism, interdisciplinarity, sex-role behavior, social construction
} 